Marquette University

e-Publications@Marquette

College of Communication Faculty Research and

Publications

Communication, College of

$1-1-2007$

\title{
Who Is a Journalist and Why Does it Matter? \\ Disentangling the Legal and Ethical Arguments
}

Erik Ugland

Marquette University, erik.ugland@mu.edu

Jennifer Henderson

Trinity University

Accepted version. Journal of Mass Media Ethics, Vol. 22, No. 4 (2007): 241-261. DOI. (C) 2007 Taylor

$\&$ Francis. Used with permission. 


\title{
Who Is a Journalist and Why Does It Matter? Disentangling the Legal and Ethical Arguments
}

\author{
Erik Ugland \\ Digital Media and Performing Arts, Marquette University \\ Milwaukee, WI \\ Jennifer Henderson \\ Communication, Trinity University \\ San Antonio, TX
}

\begin{abstract}
The contemporary debate about "who is a journalist" is occurring in two distinct domains: law and professional ethics. Although the debate in these domains is focused on separate problems, participants treat the central question as essentially the same. This article suggests that the debates in law and professional ethics have to be resolved independently and that debate within those domains needs to be more nuanced. In law, it must vary depending on whether the context involves constitutional law, statutory law, or the distribution of informal privileges by government officials. In professional ethics, the debate should not be oriented around a single definitional threshold but should identify tiers that take account of different communicators' unique goals, tactics, and values.
\end{abstract}

\section{Introduction}

The burgeoning of media technology and the evolution of news formats has made the issue of journalistic identity more complicated and consequential. Courts have had to define more clearly the people entitled to claim legal protections traditionally provided to journalists, while mainstream reporters and editors have been challenged to 
differentiate themselves from the emergent class of bloggers, dilettantes, and do-it-yourselfers. At the same time, mainstream journalists continue to battle each other for the loyalties of readers and viewers who are increasingly sympathetic to charges that the established media are feckless, shallow, or biased.

It is difficult to say whether the debate over the question of "who is a journalist" has been fruitful. Courts and legislatures have adopted disparate definitions, and many journalists seem to be growing weary of the discussion. In an online forum hosted by the Poynter Institute, for example, one reporter insisted that "we all know what a journalist is, and it's silliness to argue about it," while another dismissed the whole matter as "just so much sanctimonious bullshit" (Poynter, 2001). We believe the discussion ought to be continued, but it will never be productive unless the parties are clear about the aims of the inquiry and the contexts in which the answers are relevant. The matter of who is a journalist is salient in at least two separate domains: law and professional ethics. Within each of these domains are multiple contexts in which the question is relevant, each with its own purposes and consequences.

This article describes and evaluates the attempts by courts, legislators, and other government officials to fashion a definition of journalist, to assess their failures and successes, and to explain how their efforts are relevant-or not-to the search for a definition in the professional ethics domain. It also proposes a set of categories to use in distinguishing the work of various communicators in that domain.

\section{Differentiating the Central Domains}

Some people resolve the question of who is a journalist by leaning on clichés or making "I-know-it-when-I-see-it" kinds of arguments. Others believe the question should not be addressed at all, fearing that any agreement on a definition might be a first step toward "licensing of journalists and ultimately to censorship" (Meyer, 2002, p. $11 \mathrm{~A})$. Between those extremes, however, are a number of discrete arguments distinguished either by their core assumptions or their particular points of emphasis. 
The central problem is that participants in the debate have presented their individual conceptions of journalist as universal, without regard to the peculiarities of context. At the broadest level, they have failed to specify the domains in which they are operating (law versus professional ethics), even though the aims of the inquiry are quite different in each. Also, participants have failed to acknowledge important distinctions within those domains and the inevitability, if not the necessity, of recognizing and applying more than a single definition.

Although it is important to draw distinctions between law and ethics in exploring the issue of journalistic identity, these two domains are overlapping and interdependent. By illuminating fundamental human values and moral imperatives, ethics helps give force and legitimacy to legal mandates. By demarcating the boundaries of citizens' behavior, law accomplishes through coercion what ethics is often unable to achieve solely through appeals to conscience. Law and ethics are also related in that they are both concerned with the advancement of some socially shared vision of the public good. Nevertheless, the debates in each of these domains have clearly different purposes.

The law domain is shaped by the classical liberal ideas of autonomy, reason, and self-determination and is best characterized by libertarian press theory and its tangents, which assume that society is best served by removing all but the most essential barriers to free expression (Rivers, Schramm, \& Christians, 1980). Because it is presupposed in this domain that "debate on public issues should be uninhibited, robust and wide open" (New York Times v. Sullivan, 1964, p. 270) and that the public is enriched by its exposure to "diverse and antagonistic sources" of information (Associated Press $v$. U.S., 1945 , p. 20), the bias is toward an expansive definition of journalist.

In the professional ethics domain, the motive for defining a journalist is not to enable free expression but to separate credible contributors from less credible ones by establishing benchmarks of professional practice and measuring people against them. It is exclusive, not inclusive. Here, theories emphasizing social 
responsibility, shared commitments, and other communitarian ideals are dominant (see Rivers et al., 1980; Nerone, 1995; Commission on Freedom of the Press, 1947). Unlike in the law domain where there is resistance to discrimination among speakers, here it is essential. While the legal debate is about people's ability to freely contribute news and information in the ideas marketplace, the professional ethics debate is about the relative value of those contributions. Those kinds of qualitative judgments are enabled by, and help reinforce, narrower definitions than those favored in law.

The basic distinctions between law and professional ethics are rarely made in this debate.

The basic distinctions between law and professional ethics are rarely made in this debate. Legal and ethical arguments are routinely juxtaposed in falsely dichotomous ways, which either misdirects or halts the dialog. An article in Quill, a publication of the Society of Professional Journalists, provided one small example. It quoted Tom Rosenstiel of the Committee of Concerned Journalists, who argued that journalism is not about affiliations but actions. "You can't say, 'I'm a journalist, here's my press pass,' " Rosenstiel said. "You have to say, 'I'm a journalist. Here's my work.' Some of the people with press passes don't make the cut" (Barton, 2002, p. 11). This was contrasted with what the writer described as the "broader, more inclusive view" of Lucy Dalglish, head of the Reporters Committee for Freedom of the Press, who suggested that a journalist is "someone who is collecting information with the purpose of disseminating it to the public" (Barton, 2002, p. 11).

These comments were presented as competing points of view, when in fact they were aimed at completely different questions, or at least different aspects of the same question. Their attentions might have been focused on the same phrase-who is a journalist-but Rosenstiel was clearly working in the domain of professional ethics, trying to aid our judgments about whom to trust in the world of news, while Dalglish was clearly working in the domain of law, trying to propose some minimum eligibility standard for access to legal 
protections. Both opinions are reconcilable and are indeed consistent with the prevailing approaches in their respective domains: in law, an egalitarian model that emphasizes equal access to rights and privileges, and in professional ethics, an expert model that emphasizes the unique proficiencies and duties of media professionals.

It is often problematic when the language of one domain is used in the other, or when the contributors are unclear about the specific issues to which their comments are directed. People proposing narrow definitions are labeled as enemies of the First Amendment, and those proposing broader definitions are derided for giving anonymous online hacks the same treatment as the most esteemed veterans of the media mainstream. The hypersensitivity to perceived assaults on the First Amendment is particularly destructive because it impedes the more meaningful debate about what matters in the world of communication and what sources deserve our notice and trust. Because traditional journalists have the most to lose in competition with their less established rivals, it is in their interest to establish a clear professional identity. But they seem almost more apprehensive than their counterparts to participate in the debate, perhaps fearing that any attempts to define what they do might weaken their own First Amendment freedoms, or might harden their rights at the expense of someone else's, which is not an outcome most traditional journalists would celebrate.

In addition to conflating the two principal domains, the parties also overlook subtleties within them. In law, there are at least three unique contexts in which the definitional dilemma arises: constitutional law, statutory law, and informal privileges granted by government officials. Each of these requires separate analysis. The same is true in the professional ethics domain where the participants tend to build their arguments around the clumsy dichotomy of journalist/nonjournalist when a more tiered approach, with multiple definitions, might be both necessary and unavoidable. So, instead of pursuing a single set of criteria, we might recognize gradations that acknowledge the peculiar contributions and roles of different communicators. In doing so, there may be a temptation to look to the law for guidance. The definitions in that domain already exist in concrete form-they are spelled out in statutes and court opinions. However, not only are many 
of those definitions flawed, but they also are often unsuitable in the domain of professional ethics, where the focus is more on best practices than minimum standards.

\section{The Law Domain}

\section{Constitutional Law}

Although the First Amendment to the U.S. Constitution contains only 14 words devoted to speech and press, the federal courts have outlined with relative clarity the scope of people's freedom to disseminate information and ideas. The courts have been less clear about whether the First Amendment also protects people's right to gather news and whether the Constitution endows journalists with protections unavailable to other citizens. The Supreme Court has never explicitly recognized any unique protections for journalists, although a few of its decisions, perhaps inadvertently, have come close. In Philadelphia Newspapers $v$. Hepps, for example, the Court held that "the common-law presumption that defamatory speech is false cannot stand when a plaintiff seeks damages against a media defendant ..." (emphasis added) (Philadelphia Newspapers v. Hepps, 1986, p. 777). This reference was repeated in subsequent cases and was read by some as recognition of separate constitutional standards for journalists.

At least one former member of the Court, Justice Potter Stewart (1975), argued that the press status of a litigant is constitutionally relevant and that media litigants should be afforded special rights not available to the public generally. Stewart argued that the Press Clause of the First Amendment should be read separately from the Speech Clause, and that the former should be understood as an explicit guarantee of unique protections for the "institution of the press," which he defined as the "the daily newspapers and other established news media" (p. 634). Any other interpretation, Stewart said, would turn the Press Clause into a "constitutional redundancy" (p. 631). Among other things, Stewart lobbied for recognition of a "reporter's privilege." He argued that these kinds of protections are essential to facilitating the press' "organized, expert scrutiny of government" ( $p$. 634). 
Although Stewart was the only member of the Court to publicly promote this expert model of the press, much of the Court's rhetoric about the press fits comfortably within that framework. The justices routinely cast freedom of the press in instrumental terms, suggesting that neither the press nor individual journalists are free for their own purposes but to enhance "discourse for the sake of a citizenry better informed and thus more prudently self-governed" (Cohen v. Cowles Media Co., 1991, Souter dissent, p. 677). In addition, the news media have a "constitutionally established role" (Saxbe, Powell concurrence, 1974, p. 864) of fostering "discussion of governmental affairs" and other public issues (Globe Newspaper Co. v. Super Ct. for Norfolk County, 1982, p. 604). Justice White put it more bluntly in Tornillo: "The press is the servant, not the master, of the citizenry" (Miami Herald v. Tornillo, 1974, White dissent, p. 258). These references are in line with the expert model in which the press employs its unique credentials to serve as the public's proxy in its supervision of government.

Despite these indefinite references, the Court's rulings do not support Stewart's framework or the recognition of special rights. In fact, the Court plainly rejected his bifurcated construction of the First Amendment in its only reporter's privilege case, Branzburg v. Hayes (1972). In Branzburg, the Court ruled against several reporters who claimed the First Amendment protected their refusal to comply with grand jury subpoenas. The reporters argued that the subpoenas breached their editorial autonomy and threatened the sanctity of their confidential source relationships. The Court disagreed, relying on the common law maxim that the public has a right to "every man's evidence" (p. 674). One of the Court's principal concerns was that recognition of a privilege would force courts to define the class of citizens entitled to invoke its protections. This was a "questionable procedure," the Court wrote, "in light of the traditional doctrine that liberty of the press is the right of the lonely pamphleteer who uses carbon paper or a mimeograph just as much as of the large metropolitan publisher who utilizes the latest photocomposition methods" ( $p$. 704). The Court added that the "informative function asserted by representatives of the press ... is also performed by lecturers, political pollsters, novelists, academic researchers, and dramatists" (p. 705). This echoed language from one of the Court's 
earliest First Amendment cases in which it held that freedom of the press "comprehends every sort of publication which affords a vehicle of information and opinion" (Lovell v. Griffin, 1938, p. 452).

Two key models emerge from the Supreme Court's opinions: an expert model ... and an egalitarian model.

Two key models emerge from the Supreme Court's opinions: an expert model, in which journalists are conceived of as a uniquely qualified and clearly identifiable collection of professionals who serve as agents of the public in the procurement and dissemination of news, and an egalitarian model-illuminated by Branzburg and Lovell-in which all citizens are equally equipped and equally free to serve as newsgathering watchdogs. Because the Court has refused to recognize any special protections for journalists under the First Amendment, these definitional distinctions would seem to be of no consequence. But in the 35 years since Branzburg, most federal circuit courts have recognized a First Amendment reporter's privilege. They have done so not by ignoring Branzburg but by limiting it to its peculiar facts and differentiating all but the most closely analogous cases.

Although the circuit courts have taken a jaundiced view of the Branzburg ruling, they have consistently embraced its egalitarian conception of the press. What was viewed as an obstacle by the Branzburg court-the potentially boundless criteria for eligibility-has been treated by the lower courts as the privilege's saving grace. In fashioning more wide-ranging definitions that are not tied to salary, education, experience or other credentials, the lower courts have effectively solved the "special rights" dilemma by making the privilege available to any citizen industrious enough to seek and report news.

The most widely cited test in recent opinions is the one articulated by the Second Circuit in Von Bulow v. Von Bulow (1987). It requires that the person claiming the privilege show "the intent to use the material-sought, gathered, or received-to disseminate information to the public and that such intent existed at the inception of the newsgathering process" (p. 144). The Ninth Circuit and the D.C. 
Circuit have explicitly endorsed that test, and the Third Circuit has adopted one that is nearly identical, except that it emphasizes "investigative reporting" (In re Madden, 1998, p. 130). Several other circuits have addressed the issue less formally, but all have shown a clear preference for functional criteria, such as the intent of the newsgatherer and the nature of the information, rather than on the medium employed or the newsgatherer's expertise or other qualifications. The federal courts have consistently employed broad criteria and have found investigative book authors (Shoen $v$. Shoen, 1993), filmmakers (Silkwood v. Kerr-McGee, 1977), scholars (Cusumano v. Microsoft, 1998), and publishers of technical newsletters (Apicela v. McNeil Lab Inc., 1975) to be journalists for purposes of the privilege. And although the cases are not abundant, there can be little doubt that the federal courts will continue to make the privilege available to those disseminating news through newer media.

\section{Assessing the Debate}

Because debate on this track is focused on the dimensions of a constitutional right, the courts' embrace of the egalitarian model and their adoption of broad eligibility criteria are certainly warranted. The protections outlined in the Bill of Rights are fundamental and represent the core, constitutive freedoms essential for people's productive, democratic participation and their ability to lead autonomous, selfdirected lives. Furthermore, constitutional rights are not merely the means by which we advance social goals; they are the bases upon which we preserve moral principles-in this case, our individual liberty in the pursuit and expression of our perceived truths. To permit access to those rights only by those who meet certain artificial criteria would be inconsistent with the broader tenor of the Constitution, which champions equality and eschews class distinctions. As Philip Bobbitt (1982) suggested, this "constitutional ethos"-the "cadence of our rights" expressed through the document-should guide our interpretation of the Constitution's discrete passages (pp. 176-177). It is not insignificant that the other rights enshrined in the Constitution are available to all citizens equally and not to particular social subsets. That is not to say that a right can be invoked by any person in any context. A person still needs to be engaged in the underlying behavior 
that the right protects-in this case gathering and disseminating news-but factors other than behavior, such as characteristics, credentials, or affiliations, should be left out of the equation.

\section{Statutory Law}

With the exception of the reporter's privilege, which is now recognized in one form or another in most federal circuits, the courts have not interpreted the Constitution as providing any special rights for journalists. Congress and the state legislatures, however, have passed a number of laws creating some unique protections. Thirtythree states and the District of Columbia have passed shield laws that give journalists explicit protections against certain subpoenas, and as of this writing there are two bills before Congress that would establish a federal shield law. Thirty-one states have also passed retraction statutes that allow media defendants to minimize their liability in defamation suits by retracting the allegedly defamatory material. Some states' long-arm statutes, which govern courts' jurisdiction over various litigants, provide special dispensation for media defendants. Also, some freedom of information (FOI) laws waive the search fees and photocopying costs when the requester is a journalist.

Most of these laws contain some language defining "journalist" or "the press," but they are much narrower and more focused on traditional media than the definitions used by courts in First Amendment reporter's privilege cases. Both the statutory language and the statements made by courts interpreting those statutes are reflective of an expert conception of the press, which is manifest in several ways. One is by an emphasis on occupational status. The language from the Florida shield law is typical in that it defines a journalist as "a person regularly engaged in [newsgathering] for gain or livelihood, who obtained the information sought while working as a salaried employee ..." (emphases added). Similarly, the D.C. shield law requires that a person be "employed by the news media;" the Indiana law requires a person to be "an editorial or reportorial employee, who receives or has received income" for newsgathering; and the Delaware law even includes a requirement that a person be employed at least 20 hours per week before he or she qualifies. Other references to employment are less definite, such as the laws in Alaska, Illinois, 
Louisiana, and North Carolina, which refer to those engaged "in the business" of newsgathering.

Most shield laws also limit their application to material disseminated in particular media. The North Dakota statute provides a more egalitarian example in that it protects journalists working for "any organization engaged in publishing or broadcasting news," but most other statutes specifically identify the covered media, which presumably excludes those not mentioned. The Nebraska law provides a more exhaustive list than most-it protects "any newspaper, magazine, other periodical, book, pamphlet, news service, wire service, news or feature syndicate, broadcast station or network, or cable television system"-and yet it still leaves out scholars, documentarians, bloggers, and many others. Some statutes also add vague qualifiers, such as the Indiana law that says individuals must be "bona fide" employees of "legitimate" news organizations and the Rhode Island law that requires that someone work for an "accredited" news organization, whatever that is. The lists of covered media included in the two bills before Congress are comprehensive, although an earlier version of the Senate bill would not have covered news organizations that publish only on the Web. Retraction statues follow similar patterns and are even more likely than shield laws to explicitly protect only traditional media. The Tennessee statute, for example, is one of several that allow a retraction to serve as a partial defense in a libel case but only where the defendant is a "newspaper or periodical." The courts have mostly taken a conservative approach to interpreting these statutes, and they occasionally color their opinions with expertmodel rhetoric. In Matera $v$. Superior Court, for example, an Arizona court held that the state shield law was "not designed to protect the information collected, but rather was designed to aid a specific classmembers of the media-in performing their jobs" (emphasis added) (Matera v. Superior Court, 1992, p. 973). Because the courts have been unwilling to reach beyond the text to protect people or media not specifically mentioned, the kinds of people commonly protected by federal courts in the constitutional privilege context are often denied statutory protection. These exclusions are not limited to unconventional newsgatherers either. Time magazine, for example-a quintessentially mainstream publication-was denied protection under the Alabama shield law because the statute mentions newspapers but 
not magazines (Price $v$. Time, 2005). The courts have taken a similarly strict approach in their interpretation of retraction statutes. The Wisconsin courts, for example, have held that because that state's statute only mentions print publications, it cannot be invoked by broadcasters (Hucko v. Joseph Schlitz, 1981) or operators of electronic bulletin boards (It's in the Cards, 1995).

The courts are not entirely to blame for these results. The basic rule of judicial review is that "any conflict between the legislative will and the judicial must be resolved in favor of the former" (Dickerson, 1975 , p. 8). So even if the courts believe a statutory definition has been too narrowly drawn, they have little discretion to amend it through judicial fiat.

\section{Assessing the Debate}

Although the legal debates over who is a journalist are often conducted under the same umbrella, the constitutional debate and the statutory debate are distinct, or should be, and are capable of pointing to different but equally legitimate conclusions. Constitutions and statutes are both valid sources of law, but there are important differences that ought to guide our inquiries as well as our scrutiny of the judgments already made by courts and legislatures.

( $T$ )he difference between constitutional law and statutory law is that the former guarantees rights while the latter confers privileges.

Fundamentally, the difference between constitutional law and statutory law is that the former guarantees rights while the latter confers privileges. A shield law does not give journalists a right to avoid subpoenas; it merely grants them a privilege that can be taken away at the whim of a legislative majority. When we say that someone has a right to do something or to refrain from doing it, we mean, as Dworkin (1978) put it, "that it would be wrong to interfere with his doing it" (p. 188). We do not mean wrong in the practical sense of it being ill-advised; we mean wrong in the moral sense of it being a 
violation. This distinction is akin to the one Dworkin made between policies and principles. A policy is "that kind of standard that sets out a goal to be reached, generally an improvement in some economic, social, or political feature of the community," whereas a principle is "a standard that is to be observed ... because it is a requirement of justice, or fairness or some other dimension of morality" (p. 22). The Constitution is the guarantor of rights and is society's ultimate expression of principle. Statutes, on the other hand, are merely the tools by which we direct our day-to-day lives and are more strictly utilitarian.

Many arguments can and should be made in favor of more egalitarian statutory definitions. Statutes that require a claimant to be engaged in newsgathering as part of their employment or "for gain or livelihood" are hard to defend in a world where some of the most important news stories are broken by bloggers working without pay or institutional affiliations. Statutes that fail to include Internet communicators in their lists of covered parties, then, are underinclusive and in need of amendment. For that matter, statutes that offer blanket coverage for all employees of traditional news organizations are overinclusive. Why should a travel writer for a newspaper be afforded more protection than, say, a Pulitzer-Prize winning author of investigative books on American politics? One solution would be to simply redraw the lines in ways that are more encompassing. A better approach, however, and one that addresses the overinclusiveness problem, is to use the same functional criteria that the federal courts have employed in the constitutional context. This gives the courts the ability to make more nuanced determinations to ensure that those who need protection get it and those who don't are not using it to evade an otherwise valid subpoena.

The same approach should be used with other privilege-granting laws, such as the retraction statutes, which, even more than the shield laws, are focused on conventional media. Legislators should be asked to explain why it is socially valuable to encourage newspapers to retract their false and defamatory stories but not to provide the same incentives for broadcasters, bloggers, or other mass communicators. 
NOT THE PUBLISHED VERSION; this is the author's final, peer-reviewed manuscript. The published version may be accessed by following the link in the citation at the bottom of the page.

\section{Informal Privileges}

In addition to the constitutional and statutory rights and privileges provided to journalists, government officials often confer other benefits that can present legal, ethical, and practical problems. The Supreme Court sets aside seats in its courtroom for use by certain news organizations. The President invites some members of the press to accompany him on Air Force One. Members of Congress often allow only credentialed journalists to attend their news conferences. And there are a host of other contexts in which public officials at all levels of government serve as the arbiters of access. They must establish criteria by which to make those determinations, but more as a matter of fairness than law.

For the most part, public officials have no obligation to make special arrangements for the press. Courts have consistently held that there is no First Amendment right of access to places (Houchins $v$. KQED, 1978)-courtrooms being the only exception (Richmond Newspapers $v$. Virginia, 1980)-and that elected officials have no legal obligation to speak to the press (Baltimore Sun Co. v. Erlich, 2006). This discretion, however, is not without limit. The government's greater authority to deny access entirely does not include the lesser authority to discriminate on the basis of viewpoint, for example. Public officials are given wide latitude, and they generally open their doors to traditional media that reach the widest audiences.

\section{Assessing the Debate}

By denying access, government officials are certainly limiting opportunities for the acquisition of news, but because they have no obligation to provide access in the first place the denials do not take on a constitutional dimension. This is true even if the government provides access to some and not others (except in those situations where the decisions are made on the basis of viewpoint or on the basis of immutable characteristics such as race or gender). There should be no expectation, then, that government officials will favor the wideranging criteria of the egalitarian model in making their access determinations. 
Indeed, even as a simple matter of policy, that kind of encompassing definitional standard would probably be unworkable. Officials must take into account practical considerations in this context that are not present in the constitutional context-namely, the finite space available in which to accommodate media representatives. Only so many individuals can physically fit into the White House Press Room or the House and Senate chambers. A truly egalitarian access policy might not be feasible in light of these practical problems and administrative burdens. At some point, officials would be forced to ask whether implementing such a policy would ultimately misdirect the time and efforts of government employees who must attend to the public's business. If constitutional rights were involved, the government would be expected to absorb more of these burdens, but in the context of informal administrative policymaking, officials are free to engage in more straightforward cost-benefit analyses.

For many of the reasons just noted, the definitional issue in the access context can also be distinguished from that in the statutory context. The same kinds of practical and administrative considerations are applicable, and government officials are under no legal obligation to adopt broad criteria. This would be different if, for example, they were being asked to implement a statute that guaranteed access for journalists but that did not include a clear definition. In that case, there would be a popular mandate in favor of access that would have to be respected. But in the typical access/informal privilege situation, the courts would likely view these decisions as more akin to housekeeping than policymaking.

Legally, then, government officials have little compulsion to accommodate the interests of journalists; indeed, they need not provide access at all. On the other hand, it is not unreasonable to expect them to embrace more egalitarian approaches. This might seem like a quaint expectation in a world of cold partisanship, but public officials still do have a duty to act in ways that put society's collective interests ahead of their own. 
NOT THE PUBLISHED VERSION; this is the author's final, peer-reviewed manuscript. The published version may be accessed by following the link in the citation at the bottom of the page.

\section{The Professional Ethics Domain}

Unlike in the law domain where courts and legislatures establish definitions that are imposed upon others, in the professional ethics domain the definitional question ultimately rests with individual media consumers. In this domain, no one has the power to mandate adherence to a particular definition, nor is it necessary to seek any kind of social consensus. Each of us has our own conception, built around our peculiar criteria and embedded within the broader interpretive frameworks we apply to all information. So, it is perilous to orient the debate around a simple journalist/nonjournalist dichotomy when there are potentially as many definitions of journalist as there are consumers of journalism. Nevertheless, one might make some threshold distinctions that seem to represent the logical cut-lines in this domain, even though they are unavoidably imperfect. One distinction can be made between public communicators-people who disseminate newsworthy information to others but in a sporadic and unregimented way-and second-level journalists-those who gather and disseminate news more deliberately, regularly and conspicuously. Another distinction can be made between second-level journalists and top-level journalists. Second-level journalists are focused solely on the dissemination of truthful, newsworthy information, as are top-level journalists. The latter, however, are also committed to gathering and telling stories in a particular way, one that honors the higher virtues that have traditionally shaped the profession. These distinctions are described more fully next, with particular attention paid to whether the definitional models from the law domain have any applicability in the domain of professional ethics.

\section{Public Communicators vs. Second-Level Journalists}

One distinction that could be made is between ordinary public communicators and what we might call second-level journalists. Public communicators are those who contribute something to the world of knowledge by disseminating ideas or information to others but who do so only occasionally or without a permanent media presence that subjects their work to the normal mechanisms of accountability. A college professor giving a public address, a witness to a terrorist attack who posts a video on You Tube, or an aspiring film critic who 
sends reviews to others through a listserv would all fall into this category, as would professionals in advertising, public relations, or other fields whose communications are not designed to report on important events occurring in society.

$$
\begin{gathered}
\text { Second-level journalists ... are } \\
\text { engaged in ... regular, } \\
\text { systematic, and conspicuous } \\
\text { dissemination of news }
\end{gathered}
$$

Second-level journalists, on the other hand, are engaged in a more regular, systematic, and conspicuous dissemination of news. Unlike other public communicators, their efforts are continuous and their contributions are made with some predictability and purpose; they are not simply incidental to some other goal. Second-level journalists' raison d'être is the communication of what they in good faith believe is truthful information. However, unlike top-level journalists, they do not adhere to the standards of practice and core values that have traditionally defined the profession and that are promulgated in industry codes (e.g., the Society of Professional Journalists Code of Ethics) and organizational handbooks (e.g., the New York Times' "Ethical Journalism Handbook").

Because the current debate over journalistic identity was triggered by the emergence of bloggers and other Web communicators, the participants in the professional ethics domain tend to structure their arguments in ways that separate new media and old media. Their definitions focus on differences in technology and medium instead of content, function, and method. This is certainly true with respect to bloggers who are regularly represented as functionally indistinguishable from one another, as in this sweeping denunciation by the Wall Street Journal's Joseph Rago: "Every conceivable belief is on the scene, but the collective prose, by and large, is homogenous: a tone of careless informality prevails; posts oscillate between the uselessly brief and the uselessly logorrheic" and "complexity and complication are eschewed" (2006, p. A18).

This broad-brushing is also common in polls. A survey by the Pew Internet \& American Life Project, for example, found that 65 
percent of bloggers do not see their work "as a form of journalism" (Lenhart \& Fox, 2006, July 19). A University of Connecticut (2006) poll found that traditional journalists have a "low regard" for "news" presented in blogs, and that only 11 percent of journalists rate news on blogs as "excellent" or "good." According to a BBC poll, only 25 percent of the public says it has "a lot" or "some" trust in blogs (BBC/Reuters/Media Center, 2006). These surveys might be helpful for some purposes, but they do little to advance the definitional debate. As of early 2007, 12 million Americans operated blogs (Kirsner, 2007, February 4), so asking people how they feel about them is like asking people how they feel about "broadcasters" without distinguishing between Rush Limbaugh, Matt Lauer, and Christiane Amanpour.

It is no doubt tempting to use technology as a short-cut means of characterizing and differentiating communicators. Many state legislatures have used the same approach in fashioning the pressprotective statutes described earlier. But journalism has never been understood as residing in a particular medium, so for any definitions and categories to be useful, they must move beyond these structural features to consider the ways in which the medium is being used. Those who might be described as second-level journalists, therefore, come from across the media spectrum and could include bloggers like Ariana Huffington (Huffington Post) and Markos Moulitis (Daily Kos), websites like Newsmax, print publications like The Progressive and The American Prospect, and even television programs like Countdown with Keith Olberman or The Daily Show with Jon Stewart. Each of these is a source of news, even though it is occasionally coupled with opinion or embedded within a larger work of satire. Each is produced regularly and displayed prominently. Each presents itself as a news source (less so with The Daily Show) and deliberately enters itself into a journalistic culture in which its work is critiqued and rebutted. And each is focused on the dissemination of what its contributors believe to be the truth, even though they are not reliably attuned to the touchstones of toplevel journalism, for example, objectivity, balance, completeness, and proportionality.

Many second-level journalists explicitly disavow the label of journalist, either because they conceive of themselves differently or because they do not want to be subjected to the more exacting 
standards of the top level. Others embrace the term, however, either to secure rights or privileges or to position themselves as trustworthy arbiters. What many of them seek is simply the recognition that their work has value and that it is to be believed, something that, to some anyway, is connoted by the word "journalist."

Much of the commentary from second-level journalists has a triumphant, egalitarian ring to it, and there are some clear parallels between the rhetoric in the professional ethics domain and the egalitarian standards that often prevail in law. They both reject the idea that the truth can only be told by properly trained and educated specialists. They reject the idea that the freedom to gather news is a superfluity for anyone working outside the media mainstream. Their conception of journalism is one that emphasizes its function and content and not its structure or institutional imprimatur. They might not suggest that everyone is a journalist, but they certainly believe anyone can be, and no law or bureaucracy or professional association ought to be able to thwart or delegitimize those efforts. Despite these similarities, the minimum-standards criteria of the legal domain's egalitarian model are actually more permissive than those of secondlevel journalism. In some jurisdictions, for example, a university professor or a documentary filmmaker might meet the requirements for invoking the journalist's privilege but would not be engaged in the kind of continuous collection, synthesis, and dissemination that define second-level journalism. So, even though the egalitarian model from the law domain might be useful in locating the distinctions among communicators in the ethics domain, they are not perfectly interchangeable.

The expert model is even less applicable here. One could argue that even second-level journalists use expert rhetoric in separating themselves from ordinary public communicators. That might be true in some instances, but it is certainly not as common among second-level journalists as it is among top-level journalists. The former, even in distinguishing themselves from public communicators, are less likely to emphasize their unique expertise or credentials than they are simply to identity the ways in which what they do is different. 
NOT THE PUBLISHED VERSION; this is the author's final, peer-reviewed manuscript. The published version may be accessed by following the link in the citation at the bottom of the page.

\section{Second-Level vs. Top-Level Journalists}

The second and perhaps more important distinction that might be made in the domain of professional ethics is between second-level journalists, who are principally focused on truthfully communicating news to others, and top-level journalists, who are not merely concerned with telling the truth but also with honoring the ethical canons of traditional American journalism, such as independence, proportionality, comprehensiveness, and accountability.

There are many bases upon which traditional (top-level) journalists have sought to set themselves apart-training, education, affiliation-but their actions are ultimately what define their work, not these peripheral credentials. The debate in this domain is too often sidetracked by these expert-model characteristics when what really matters-indeed the only things that matter-are the standards of practice that journalists follow in their pursuit and dissemination of news.

Training. Some top-level journalists will point to their education, either on-the-job or in journalism schools, as a way of separating themselves from other public communicators. To them, education, like affiliation (discussed below), is often seen as a foundation for ethical standards of practice. It is in these formal settings (newsrooms or classrooms) that ethical values are introduced and reinforced. The value of education in making this distinction is seen among those studying journalism as well as those practicing it. For example, one student at the Columbia Graduate School of Journalism said a journalist was a "trained writer" who "perceives an event and reports it accurately" (Konner, 1996, p. 4).

Top-level journalists are more than just chroniclers of events. They see journalism as a "call to search for the truth" (Konner, 1996, p. 4). As former Washington Post editor Howard Simons noted:

People who come into the newspaper business are somewhat hyperactive, somewhat creative and somewhat causists. I don't mean that in the contemporary sense of the word. I mean they

Journal of Mass Media Ethics, Vol. 22, No. 4 (2007): pg. 241-261. DOI. This article is @ Taylor \& Francis (Routledge) and permission has been granted for this version to appear in e-Publications@Marquette. Taylor \& Francis (Routledge) does not grant permission for this article to be further copied/distributed or hosted elsewhere without the express permission from Taylor \& Francis (Routledge). 
NOT THE PUBLISHED VERSION; this is the author's final, peer-reviewed manuscript. The published version may be accessed by following the link in the citation at the bottom of the page.

have some sense, rooted in their stomach, of injustice which the newspaper gives them an instrument to correct. (Cannon, 1997, p. 13)

Those fighting to right wrongs are now as likely to be found in the blogosphere as they are in the A sections of local newspapers.

Interestingly, this describes individuals whom many top-level journalists would likely exclude from their category. Those fighting to right wrongs are now as likely to be found in the blogosphere as they are in the A sections of local newspapers.

Affiliation. Some of those engaged in the debate in the professional ethics domain have suggested that a true journalist must be associated with an organization (usually brick and mortar) whose primary work is the business of producing news. Applying this restriction, Washington Post editors and CNN reporters would be journalists, but most bloggers, and even those working for online news organizations such as Slate.com or The Hotline, might not. In addition, commentators like Bill O'Reilly and Maureen Dowd would be considered journalists, even though they are not necessarily committed to the traditional standards of practice.

Standards of Practice. Top-level journalists find moral duty in their occupations and take seriously the idea that journalism is a public trust. These commitments are often expressed through their codes of ethics (although there are certainly some top-level journalists who honor these principles without writing them down or professing them publicly). The codes, which can be traced to the beginning of printing in the United States and which were concretized in the early 20th century by organizations such as the American Society of Newspaper Editors and the Society of Professional Journalists, provide a set of professional benchmarks that reflect a kind of fiduciary spirit. The codes articulate the underlying values of the profession and detail behaviors the public has come to expect: neutrality, independence, accountability, and comprehensiveness. They also suggest that permission has been granted for this version to appear in e-Publications@Marquette. Taylor \& Francis (Routledge) does not grant permission for this article to be further copied/distributed or hosted elsewhere without the express permission from Taylor \& Francis (Routledge). 
journalists minimize harm in pursuing the news, that they stay cognizant of the public interest, and that they serve as reliable watchdogs of powerful people and institutions. Some individual journalists or organizations go even further, of course, and suggest that journalism is also about giving voice to the voiceless or healing society's wounds.

Still others focus less on these behavioral guidelines and more on the traits exhibited by individual journalists. Ugland and Slattery (2006) argued that top-level journalists (what they called "true professionals") are those who follow particular habits of reliable reporting and whose "judgment, character and introspection" gives their work special weight (par. 6). Journalists exercise good judgment "by recognizing ethical problems when they arise" (par. 7), they demonstrate character when they empathize with others and make selfless decisions, and they act introspectively when they regularly reflect on the long-term impact of their work.

What all of these examples have in common is that they reject affiliation, training, and education as legitimate bases upon which to differentiate journalists and instead emphasize the broader social impact of journalism and the responsibilities of journalists to act as stewards of the public interest. That requires a great deal more than merely telling the truth.

\section{Distinguishing the Legal Definitions}

Because the egalitarian model in the law domain provides all communicators equal protections, it is of no use when deciding who is a top-level journalist. Those debates should instead be focused on the elucidation of criteria by which we can assess the value of people's contributions to the marketplace of ideas. They are pointedly about separating the good from the mediocre and the mediocre from the bad, about making plain declarations about the social value of content and of content providers. The constitutional law debate, by contrast, is not about the value of particular communications but about the "equal concern and respect" (Dworkin, p. 180) we must show for the communicators. The egalitarian model is also not helpful here because it does not help us, as consumers of news, differentiate news providers

Journal of Mass Media Ethics, Vol. 22, No. 4 (2007): pg. 241-261. DOI. This article is @ Taylor \& Francis (Routledge) and permission has been granted for this version to appear in e-Publications@Marquette. Taylor \& Francis (Routledge) does not grant permission for this article to be further copied/distributed or hosted elsewhere without the express permission from Taylor \& Francis (Routledge). 
based on the content of their work. The egalitarian model is more focused on structural characteristics and the most basic behavioral characteristics but is not a useful framework for evaluating content.

The expert model, created by statutory distinctions, may seem at first glance to be a better fit. Here, categories of individuals affiliated with institutions, or set apart by education, or by time spent on the job, or with work published in a specific medium are declared "journalists" under the law. The problem, of course, is that these distinctions are arbitrary (especially in a digital world) and focus on who someone is rather than on what he or she does. These statutes have nothing to do with weighing the relative merit of each writer but instead single out those who work in traditional newsrooms for legal protection while abandoning all other communicators.

\section{Conclusion}

As power shifts away from a handful of traditional news organizations toward a diverse collection of individuals and institutions, the matter of who defines the parameters of journalistic behavior must also shift. While once the sole domain of news associations such as ASNE and RTNDA, the ethical guidelines of news in the 21st century will increasingly be formulated by creators and audience members unaffiliated with formal institutions. Ultimately, in the professional ethics domain, the question of who is a journalist is in the eye of the beholder. Consumers decide for themselves who is a journalist, who is to be believed and whom to offer their attention and esteem.

In the law domain, fundamental rights are at stake, so the consequences of defining protections for newsgathering and expression too narrowly (especially when the party drawing the line is the government) are substantially greater than in the professional ethics domain where the debate is more about virtue than freedom. In the legal domain, there is an element of coercion-the exercise of government power to restrain behavior. That is not true in the professional ethics domain. There, it is about a private dispute among communicators regarding whose work is more valuable. 
NOT THE PUBLISHED VERSION; this is the author's final, peer-reviewed manuscript. The published version may be accessed by following the link in the citation at the bottom of the page.

"Who is a journalist?" is often treated as a single question, capable of a single answer. But, those four words are really just a vessel for a group of distinct definitional questions. The problem is not merely that the participants are approaching the issue from different perspectives and through their own particular prisms, but that they have convinced themselves that this is really about a single question rather than several. There are, in fact, two central domains in which the definitional question is being contested and several discrete contexts within those domains. By conflating these, we short-circuit a vital debate in professional ethics and push the debate in law toward excessively narrow standards of eligibility.

\section{References}

1. Apicela v. McNeil Lab., Inc., 66 F.R.D. 78 (E.D.N.Y. 1975)

2. Associated Press v. U.S., 326 U.S. 1 (1945)

3. Baltimore Sun Co. v. Ehrlich, 356 F. Supp. 2d 577, (4th Cir. 2006)

4. Barton, G. 2002. What is a jour*na*list?. Quill, 90 4, May

5. BBC/Reuters/Media Center. May 3 2006. Trust in the media May 3, http://www.globescan.com/news archives/bbcreut.htmlRetrieved Feb 5, 2007, from

6. Bobbitt, P. 1982. Constitutional fate: Theory of the constitution, New York: Oxford University Press.

7. Branzburg v. Hayes, 408 U.S. 665 (1972)

8. Cannon, L. 1997. "The socialization of reporters". In Do the media govern, Edited by: Iyengar, S. and Reeves, R. 9-17. Thousand Oaks: Sage Publications.

9. Cohen v. Cowles Media Co., 501 U.S. 663 (1991)

10. Commission on Freedom of the Press. 1947. A free and responsible press: A general report on mass communications-newspapers, radio, motion pictures, magazines, and books, Chicago: University of Chicago Press.

11. Cusumano v. Microsoft, 162 F.3d 708 (1st Cir. 1998)

Journal of Mass Media Ethics, Vol. 22, No. 4 (2007): pg. 241-261. DOI. This article is @ Taylor \& Francis (Routledge) and permission has been granted for this version to appear in e-Publications@Marquette. Taylor \& Francis (Routledge) does not grant permission for this article to be further copied/distributed or hosted elsewhere without the express permission from Taylor \& Francis (Routledge). 
NOT THE PUBLISHED VERSION; this is the author's final, peer-reviewed manuscript. The published version may be accessed by following the link in the citation at the bottom of the page.

12. Dickerson, R. 1975. The interpretation and application of statutes, Toronto: Little, Brown.

13. Dworkin, R. 1978. Taking rights seriously, Cambridge, MA: Harvard University Press.

14. Globe Newspaper Co. v. Super Ct. for Norfolk County, 457 U.S. 596 (1982)

15. Herman, E. S. and Chomsky, N. 1988. Manufacturing consent, New York: Pantheon Books.

16. Hucko v. Joseph Schlitz Brewing Co., 302 N.W.2d 68 (Wis. App. 1981)

17. Houchins v. KQED, 428 U.S. 1 (1978)

18. It's in the Cards, Inc. v. Fuschetto, 535 N.W.2d 11 (Wis. App. 1995)

19. Kirsner, S. February 4 2007. Bloggers' choice: free agents, or infomercials? February 4 http://www.mercurynews.com/mld/mercurynews/news/editorial/1662 1026.htm?templa=contentModules/printstory/jspSan Jose Mercury News online. Retrieved Feb. 5, 2007, from

20. Klaidman, S. and Bauchamp, T. 1987. The virtuous journalist, New York: Oxford University Press.

21. Konner, J. 1996. A journalist is.... Columbia Journalism Review, 35 November/December: 4

22. Kovach, B. and Rosenstiel, T. 2001. The Elements of Journalism, New York: Crown Publishing.

23. Lambeth, E. 1992. Committed journalism: An ethic for the profession, Bloomington, IN: Indiana University Press.

24. Lenhart, A. and Fox, S. 2006. Bloggers: A portrait of the internet's new storytellers. Pew Internet and American Life Project, July 19: ii

25. Lovell v. Griffin, 303 U.S. 444 (1938)

26. In re Madden, 151 F.3d 125 (3d Cir. 1998)

Journal of Mass Media Ethics, Vol. 22, No. 4 (2007): pg. 241-261. DOI. This article is @ Taylor \& Francis (Routledge) and permission has been granted for this version to appear in e-Publications@Marquette. Taylor \& Francis (Routledge) does not grant permission for this article to be further copied/distributed or hosted elsewhere without the express permission from Taylor \& Francis (Routledge). 
NOT THE PUBLISHED VERSION; this is the author's final, peer-reviewed manuscript. The published version may be accessed by following the link in the citation at the bottom of the page.

27. Matera v. Superior Court, 825 P.2d 971 (Ariz. App. 1992)

28. McChesney, R. 1999. Rich media, poor democracy, Urbana, IL: University of Illinois Press.

29. Merritt, D. 1998. Public journalism and public life, Mahwah, NJ: Lawrence Erlbaum.

30. Meyer, P. 2002. What defines a Journalist?. USA Today, January 2: $11 \mathrm{~A}$

31. Miami Herald Publishing Co. v. Tornillo, 418 U.S. 241 (1974)

32. Mohl, J. D. 2002. Definition of journalism a sticky question. Quill, 90 May: 3

33. Nerone, J. C. 1995. Last rights: Revisiting four theories of the press, Urbana, IL: University of Illinois Press.

34. New York Times v. Sullivan, 376 U.S. 254 (1964)

35. Philadelphia Newspapers v. Hepps, 475 U.S. 767 (1986)

36. http://www.poynter.org/centerpiece/091800feedback.htmPoynter Institute Online. (2001, September 1). Feedback: Who is a journalist? Retrieved May 31, 2006, from

37. Price v. Time, 416 F.3d 1327 (11th Cir. 2005)

38. Rago, J. 2006. The blog mob. The Wall Street Journal, December 20: A18

39. Richmond Newspapers v. Virginia, 448 U.S. 555 (1980)

40. Rivers, W., Schramm, W. and Christians, C. 1980. Responsibility in mass communication, New York: Harper and Row.

41. Rosen, J. 1999. What are journalists for?, New Haven, CT: Yale University Press.

42. Saxbe v. Washington Post Co., 417 U.S. 843 (1974)

43. Shoen v. Shoen, 5 F.3d 1289 (9th Cir. 1993)

44. Silkwood v. Kerr-McGee, 563 F.2d 433 (10th Cir. 1977)

Journal of Mass Media Ethics, Vol. 22, No. 4 (2007): pg. 241-261. DOI. This article is (C) Taylor \& Francis (Routledge) and permission has been granted for this version to appear in e-Publications@Marquette. Taylor \& Francis (Routledge) does not grant permission for this article to be further copied/distributed or hosted elsewhere without the express permission from Taylor \& Francis (Routledge). 
NOT THE PUBLISHED VERSION; this is the author's final, peer-reviewed manuscript. The published version may be accessed by following the link in the citation at the bottom of the page.

45. Stewart, P. 1975. Or of the press. Hastings Law Journal, 26: 631

46. Ugland, E. and Slattery, K. 2006. Ethics: fewer 'journalists,' more 'professionals'

http://www.digitaljournalist.or/issue0601/ethics.htmIRetrieved Aug. 8, 2006, from

47. http://www.uconn.edu/newsmedia/2005/may05/rel05033.htmlUniversity of Connecticut Department of Public Policy, National polls of journalists and the American public on First Amendment and the media release. (May 16, 2005). \{it\} Retrieved Sept. 9, 2006, from

48. Von Bulow v. Von Bulow, 811 F.2d 136 (2d Cir. 1987) 